\title{
Prediksi Minat Kepesertaan Sektor Informal atas Kemampuan Ekonomi dalam BPJS Kesehatan di Kota Surakarta
}

\author{
Yenni Khristiana ${ }^{1 *}$, Dibyo Iskandar ${ }^{2}$ \\ 1,2Dosen Akuntansi, STIE AUB Surakarta \\ *Corresponding author's e-mail:yenni.kristi@stie-aub.ac.id
}

\begin{abstract}
Abstrak Penelitian ini bertujuan untuk memprediksi faktor-faktor yang berhubungan minat kepesertaan pada sektor informal (wiraswasta/pedagang) dalam kepesertaan BPJS Kesehatan menggunakan variabel pengetahuan, kemampuan ekonomi dan persepsi. Jenis penelitian ini adalah penelitian kuantitatif dengan menggunakan data primer yang diperoleh dengan metode wawancara menggunakan instrumen penelitian berupa kuesioner kepada 100 peserta mandiri atau BPJS Kesehatan sektor informal di wilayah Kota Surakarta dengan perhitungan slovin' dalam penetapan sampel. Teknik analisis data yang digunakan adalah Regresi Linier Berganda. Hasil penelitian menunjukan bahwa hanya variabel kemampuan ekonomi yang berpengaruh positif secara signifikan dalam memprediksi minat kepersertaan sektor informal dalam BPJS Kesehatan. Variabel pengetahuan dan persepsi masing-masing berpengaruh positif namun tidak signifikan dalam memprediksi minat kepersertaan sektor informal dalam BPJS Kesehatan.
\end{abstract}

Kata kunci:Pengetahuan, kemampuan ekonomi, persepsi, minat BPJS Kesehatan.

\section{Pendahuluan}

Sesuai pasal 14 Undang-Undang BPJS setiap warga negara Indonesia dan warga asing yang sudah berdiam di Indonesia minimal enam bulan wajib menjadi anggota BPJS Kesehatan.Peraturan Presiden Nomor 12 tahun 2013 tentang Jaminan Kesehatan mengklasifikasikan kepesertaan program Jaminan Kesehatan Nasional (JKN) dalam dua golongan yaitu Peserta Penerima Bantuan Iuran (PBI) dan Peserta Non Penerima Bantuan Iuran (Non PBI). Selama periode 3 tahun cakupan kepesertaan terus mengalami peningkatan, sampai dengan 31 Desember 2016 mencapai 171.939.254 jiwa. Jumlah peserta pada tahun 2015 mengalami peningkatan sebesar 17,51\% dibandingkan tahun 2014 (133.423.653 jiwa), dengan ratarata peningkatan jumlah peserta per triwulan sebesar 4,38\% atau 5.841.659 jiwa. Pada tahun 2016, jumlah peserta mengalami sebesar 9,66\% dibandingkan tahun 2015 (156.790.287 jiwa) dengan rata-rata peningkatan jumlah peserta per triwulan sebesar 2,42\% atau 3.787.242 jiwa. Peningkatan jumlah cakupan peserta antara lain disebabkan semakin efektifnya program pemasaran sosial yaitu melalui kegiatan sosialisasi secara langsung (sosialisasi kepada komunitas, pekerja/pemberi kerja, tokoh masyarakat/tokoh agama/masyarakat umum, dan forum komunikasi para pemangku kepentingan utama) maupun tidak langsung (kegiatan 
promosi melalui berbagai media). Cakupan kepesertaan di Indonesia dalam rangka mencapai Universal Health Coverage (UHC) dalam periode 3 tahun telah berkembang cukup pesat,hal ini tentu menjadi prestasi tersendiri mengingat apabila dibandingkan dengan negara lain penerapan program Jaminan Kesehatan Nasional (JKN) di Indonesia relatif jauh lebih singkat.Target program Jaminan Kesehatan Nasional yaitu cakupan kepesertaan nasional yang menyeluruh pada tahun 2019 atau Universal Health Coverage (UHC). Peserta BPJS Kesehatan tidak hanya menjadi diwajibkan bagi pekerja di sektor formal, namun pekerja informal juga diwajibkan menjadi peserta BPJS Kesehatan untuk mencapai target tersebut

Berdasarkan data Badan Pusat Statistik (BPS) diketahui bahwa sampai dengan Mei 2015, di Indonesia tercatat 122,3 juta pekerja yang terdiri dari sektor formal 51,4 juta jiwa (42,06\%) dan sektor informal 70,9 juta jiwa (57,94\%).Dilihat dari konsep program Jaminan Kesehatan Nasional, sektor informal dalam kepesertaan BPJS Kesehatan termasuk kategori peserta Pekerja Bukan Penerima Upah (PBPU), dimana capaian kepesertaan kelompok ini masih rendah yaitu 7\% dari keseluruhan jumlah penduduk di Indonesia.Kota Surakarta merupakan salah satu kota di Provinsi Jawa Tengah yang memiliki potensi pekerja sektor informal cukup besar dan cakupan kepesertaan BPJS Kesehatan yang masih rendah.

Berdasarkan data masterfile BPJS Kesehatan, jumlah Peserta JKN - KIS Kota Surakarta per 30 Desember 2017 sebanyak 484.748 jiwa dari total penduduk Kota Surakarta 558.698 jiwa atau $86,76 \%$ jumlah penduduk. Seperti yang diutarakan Walikota Surakarta dalam sambutannya, di Indonesia khususnya di Kota Surakarta ada 3 kategori dari miskin, yaitu rentan miskin, miskin dan sangat miskin. Kategori rentan miskin inilah yang mempunyai jumlah cukup banyak, sehingga Pemerintah Kota Surakarta mengambil inisiatif kebijakan untuk menanggung warga yang masuk ketegori rentan miskin menjadi Peserta Penerima Bantuan Iuran Daerah dalam Program Jaminan Kesehatan Nasional - Kartu Indonesia Sehat (JKN - KIS). Pemberian kartu JKN - KIS dari dana APBD Kota Surakarta ini merupakan bentuk perhatian pemerintah kepada masyarakat Surakarta.

Berdasarkan data monografi Kota Surakarta tercatat Jumlah Unit Usaha dan Penyerapan Tenaga Kerja di Sektor Industri di Kota Surakarta Tahun 2018:

Tabel 1. Jumlah Unit Usaha dan Penyerapan Tenaga Kerja di Sektor Industri di Kota Surakarta Tahun 2018

\begin{tabular}{lrr}
\multicolumn{1}{c}{ Jenis Industri } & Unit Usaha & Tenaga Kerja \\
\hline Besar & 72 & 14264 \\
Menengah & 190 & 12432 \\
Industri Kecil & 1673 & 30530 \\
Industri Kreatif & 497 & 497 \\
Non Formal & 6010 & 16441 \\
Jumlah & 8403 & 74164
\end{tabular}

Sumber: Data KPPT, BMPT \& BPMPTSP Kota Surakarta, diolah Bidang Pengembangan Komoditi Disnakerperin Kota Surakarta, Februari 2019

Berdasarkan survei pendahuluan, permasalahan yang dihadapi sektor informal dalam kepesertaan BPJS Kesehatan mandiri adalah hubungan pengetahuan, tingkat ekonomi dan 
persepsi, mengingat pendapatan sektor informal tidak menentu setiap bulannya. Perolehan informasi atas suatu produk harus dilakukan secara terstruktur sehingga tahapan yang terjadi sesuai dengan prosesnya pada UMKM (David \& Yen, 1998; Sani, Wiliani \& Husain, 2019). Di samping itu, perlunya pemberdayaan potensi masyarakat atas pemahaman secara mendalam untuk mengidentifikasi hubungan atas perilaku konsumsi masyarakat (Khristiana, Octaviani, \& Sapariyah, 2018), hal ini tentunya diperlukan oleh masyarakat dan melatarbelakangi alasan sektor informal (wiraswasta/pedangang) dalam keikutsertaan BPJS Kesehatan mandiri di Surakarta.

Penelitian Atipah (2016) dengan judul faktor yang berpengaruh terhadap minat masyarakat dalam keikutsertaan program Jamkesda di desa Banjarlor, Kecamatan Banjarharjo Kabupaten Brebes, hasil penelitian menjelaskan bahwa variabel pengetahuan dan perilaku masyarakat terhadap minat keikutsertaan Program Jamkesda. Penelitian Melinda dkk (2016) dengan judul faktor-faktor yang berhubungan dengan minat masyarakat dalam keikutsertaan BPJS mandiri di Kecamatan Bener Kabupaten Purworejo, hasil penelitian menjelaskan Variabel sikap, persepsi, dan situasi ekonomi berpengaruh signifikan terhadap minat. Penelitian Salma (2016) dengan judul faktor-faktor yang berhubungan dengan keikutsertaan masyarakat dalam jaminan Kesehatan Nasional di Desa Tegalsari Kabupaten Ponorogo, hasil penelitian menjelaskan bahwa variabel pengetahuan dan sikap dalam program JKN berpengaruh signifikan terhadap partisipasi, hubungan antar keluarga, dukungan serta pendapatan dalam partisipasi dalam program JKN juga memiliki pengaruh yang signifikan. Penelitian Wijayanto (2017) dengan judul Hubungan Pengetahuan dan Kemampuan Ekonomi Masyarakat Terhadap Aksesibilitas BPJS, hasil penelitian menjelaskan Variabel pengetahuan dan kemampuan ekonomi berpengaruh signifikan terhadap minat, sedangkan sosialisasi tidak berpengaruh terhadap minat. Penelitian Pangestika dkk (2017), dengan judul Faktor-faktor yang berhubungan dengan kepesertaan sektor infomal dalam BPJS kesehatan mandiri di kelurahan Poncol, Kecamatan Pekalongan Timur, Kota Pekalongan, dengan hasil penelitian Variabel Pengetahuan, jumlah tanggungan keluarga, dan pendapatan tidak berpengaruh signifikan terhadap minat, sedangkan variabel pengeluaran rata-rata perbulan, kemauan membayar dan dukungan keluarga berpengaruh signifikan terhadap minat. Penelitian ini bertujuan untuk mengetahui faktor-faktor yang berhubungan dengan partisipasi masyarakat dalam program jaminan kesehatan nasional di wilayah Tegalsari Ponorogo.

Dari uraian dan gap di atas, maka diperlukan suatu penelitian mengenai faktor-faktor yang mampu memprediksi hubungan kepesertaan sektor informal (wiraswasta/pedagang) dalam BPJS Kesehatan yang meliputi pengetahuan, kemampuan ekonomis dan persepsi. Penelitian ini secara spesifik menggunakan subjek penelitian yaitu kepesertaan mandiri BPJS Kesehatan di kota Surakarta.

\section{Tinjauan Pustaka}

Pengetahuan merupakan hasil tahu dan ini terjadi setelah orang melakukan penginderaan terhadap suatu objek tertentu. Penginderaan terjadi melalui panca indera manusia, yaitu indera penglihatan, indera pendengaran, indera penciuman, indera perasa dan indera peraba. Pengetahuan atau kognitif merupakan domain yang sangat penting dalam membentuk tindakan seseorang (Notoatmodjo, 2010). Pemanfaatan potensi sumberdaya yang tersedia menjadi penting khususnya bagi masyarakat untuk meningkatkan pengetahuan dan 
keterampilan untuk mencapai tujuan hidup dan mensejahterakan ekonomi (Rismayadi \& Maemunah, 2018). Pengetahuan merupakan tahap utama masyarakat untuk mengetahui informasi mengenai program BPJS Kesehatan, manfaat BPJS Kesehatan, maupun tata cara untuk menjadi peserta BPJS Kesehatan yang akan menimbulkan motivasi masyarakat dalam pengambilan sikap untuk memutuskan menjadi peserta BPJS Kesehatan.

Menurut Anderson dalam Notoatmodjo (2007) faktor yang berhubungan dengan pemanfaatan fasilitas kesehatan dalam hal ini adalah BPJS diantaranya adalah pengetahuan dan status ekonomi. Tingkat ekonomi seseorang yang menjadi prioritas utama akan mempengaruhi kemampuan untuk mengakses pelayanan kesehatan yang ada. Memiliki penghasilan yang cukup juga dapat mendorong dan menjadi bahan pertimbangan seseorang untuk menjadi peserta BPJS Kesehatan.

Persepsi nilai merupakan penilaian konsumen secara keseluruhan terhadap kegunaan suatu produk atau jasa berdasarkan persepsi atas apa yang telah didapat. Nilai merupakan ikatan yang kuat pada persepsi konsumen atas manfaat yang dipersepsikan pelanggan. Nilai yang dirasakan (perceived value) juga digunakan oleh konsumen untuk mempertimbangkan berbagai aspek layanan dengan biaya yang ditawarkan oleh beberapa perusahaan.

Pengetahuan masyarakat menjadi langkah awal untuk memperoleh informasi mengenai BPJS Kesehatan. Pengetahuan ini digunakan untuk membentuk kesadaran konsumen untuk bertindak dan memotivasi minat seseorang. Hasil penelitian yang menguji faktor pengetahuan yang memberikan bukti signifikansinya dalam hubungannya dengan partisipasi program JKN dan Jamkesda (Salma, 2016; Atipah, 2016). Hubungan antara pengetahuan atas aksesibilitas program BPJS juga membuktikan secara signifikan atas minat (Wijayanto, 2017) sementara pada penelitian Pangestika (2017) tidak membuktikan hubungan faktor pengetahuan dengan minat kepesertaan BPJS. Perbedaan temuan penelitian terdahulu melatarbelakangi untuk kembali menguji hubungan pengetahuan terhadap minat, dimana semakin tinggi tingkat pengetahuan masyarakat maka minat masyarakat untuk menjadi peserta BPJS Kesehatan akan semakin tinggi. Hipotesis alternatif pertama dinyatakan:

$\mathrm{H}_{1}$ : Terdapat hubungan Pengetahuan terhadap Minat Kepesertaan BPJS

Kemampuan ekonomi masyarakat menjadi faktor penting untuk memutuskan penggunaan layanan BPJS Kesehatan. Kemampuan ekonomi ini digunakan sebagai pertimbangan atas manfaat yang akan diterima dengan kemampuan ekonomis masyarakat terhadap produk BPJS kesehatan. Hasil penelitian yang menguji faktor dukungan pendapatan yang memberikan bukti signifikansinya dalam hubungannya dengan partisipasi program JKN (Salma, 2016). Hubungan antara situasi ekonomi membuktikan secara signifikan terhadap minat keikutsertaan BPJS (Melinda dkk., 2016), dan juga penelitian Wijayanto (2017) melalui faktor kemampuan ekonomi terhadap aksesibilitas program BPJS tetapi pada penelitian Pangestika (2017) tidak membuktikan hubungan faktor pendapatan dengan minat kepesertaan BPJS. Perbedaan temuan penelitian terdahulu melatarbelakangi untuk kembali menguji hubungan kemampuan ekonomi terhadap minat, dimana semakin tinggi tingkat kemampuan ekonomi maka berdampak pada meningkatnya minat masyarakat untuk menjadi peserta BPJS Kesehatan. Hipotesis alternatif kedua dinyatakan:

$\mathrm{H}_{2}$ : Terdapat hubungan Kemampuan Ekonomi terhadap Minat Kepesertaan BPJS

Persepsi menjadi faktor penting dalam menilai secara keseluruhan terhadap manfaat suatu produk atau jasa. Persepsi ini digunakan sebagai bahan evaluasi atas manfaat yang akan 
diterima dengan kemampuan ekonomis terhadap produk BPJS kesehatan. Hasil penelitian yang menguji hubungan sikap, persepsi ekonomi atas minat membuktikan secara signifikan minat keikutsertaan BPJS (Melinda dkk., 2016). Pengetahuan, sikap dan perilaku juga berpengaruh signifikan terhadap partisipasi program JKN dan Jamkesda (Salma, 2016; Atipah, 2016). Semakin baik persepsi masyarakat atas program BPJS Kesehatan maka berdampak pada meningkatnya minat masyarakat untuk menjadi peserta BPJS Kesehatan. Hipotesis alternatif ketiga dinyatakan:

$\mathrm{H}_{3}$ : Terdapat hubungan Persepsi terhadap Minat Kepesertaan BPJS

Hasil tinjauan pustaka di atas untuk menjawab tujuan penelitian dikaji berdasarkan tinjauan pustaka dan reviu penelitian terdahulu yang dituangkan ke dalam model penelitian. Model dapat dipahami sebagai sesuatu yang berukuran kecil yang berupa persamaan model matematika yang menunjukkan hubungan antar variabel yang saling mempengaruhi (Supranto \& Limakrisna, 2019, hal. 31). Model penelitian ini disajikan pada Gambar 1.

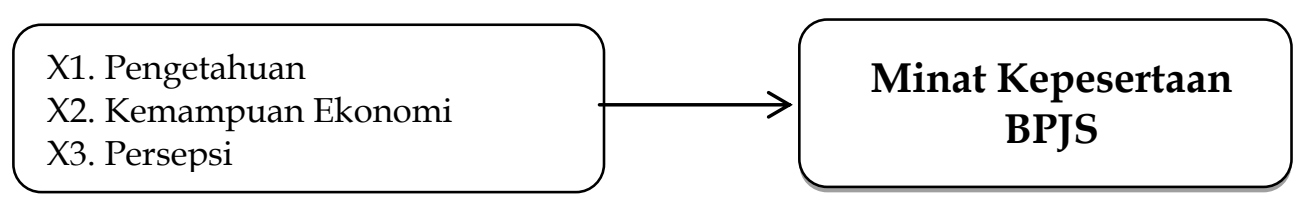

Gambar 1. Model Penelitian

Model penelitian di atas menjelaskan hubungan antara masing-masing faktor yang memprediksi Minat Kepesertaan BPJS, terdiri dari Pengetahuan (sebagai variabel X1), Kemampuan Ekonomi (sebagai variabel X2) dan Persepsi (sebagai variabel X3).

\section{Metodologi Penelitian}

Jenis penelitian ini adalah penelitian kausalitas dengan pendekatan kuantitatif, yaitu penelitian yang digunakan untuk meneliti pada populasi atau sampel tertentu, pengumpulan data menggunakan instrumen penelitian, analisis data bersifat kuantitatif dengan tujuan untuk menguji hipotesis yang telah ditetapkan (Sugiyono, 2016).

Data yang digunakan dalam penelitian ini adalah data primer didapatkan dengan metode wawancara menggunakan instrumen penelitian berupa kuesioner kepada peserta mandiri atau BPJS Kesehatan sektor informal di Wilayah Kota Surakarta. Variabel independen pada penelitian ini dioperasionalisasikan yaitu: (1) Pengetahuan menggunakan 4 (empat) item pernyataan (X1_1 - X1_4; (2) Kemampuan Ekonomi menggunakan 5 (lima) item pernyataan (X2_1 - X2_5); dan Persepsi juga menggunakan 5 (lima) item pernyataan (X3_1 - X3_5), sedangkan variabel dependen pada penelitian ini adalah Minat Kepersertaan Sektor Informal dalam BPJS Kesehatan di Kota Surakarta pada Tahun 2020 menggunakan 5 (lima) item pernyataan (Y_1 - Y_5).

Teknik analisis data yang digunakan adalah Regresi Linier Berganda, dimana akan diuji dengan uji t, uji F dan uji adjusted $\mathrm{R}^{2}$. Populasi dalam penelitian ini seluruh peserta mandiri atau peserta BPJS Kesehatan sektor informal yang terdaftar pada wilayah kerja Kota Surakarta yaitu sebanyak 2463 jiwa. Penentuan sampel menggunakan rumus Slovin dari perhitungan rumus didapati sampel dalam penelitian ini sebanyak 100 responden. 


\section{Buana Akuntansi}

\section{Analisis dan Pembahasan}

\subsection{Uji Validitas dan Reliabilitas Data}

Tabel 1.Hasil uji item pernyataan untuk variabel Pengetahuan $\left(X_{1}\right)$

\begin{tabular}{|l|r|r|r|r|}
\multicolumn{7}{|c|}{ Item-Total Statistics } \\
\hline & $\begin{array}{c}\text { Scale Mean if } \\
\text { Item Deleted }\end{array}$ & $\begin{array}{c}\text { Scale } \\
\text { Variance if } \\
\text { Item Deleted }\end{array}$ & $\begin{array}{c}\text { Corrected } \\
\text { Item-Total } \\
\text { Correlation }\end{array}$ & $\begin{array}{c}\text { Cronbach's } \\
\text { Alpha if Item } \\
\text { Deleted }\end{array}$ \\
\hline X1_1 & 12,1300 & 3,670 &, 706 &, 810 \\
X1_2 & 12,3300 & 3,496 &, 651 &, 833 \\
X1_3 & 12,3900 & 3,291 &, 725 &, 800 \\
X1_4 & 12,2300 & 3,633 &, 705 &, 810 \\
\hline
\end{tabular}

Sumber: Output SPSS (2020)

Keseluruhan butir pernyataan untuk variabel Pengetahuan $\left(\mathrm{X}_{1}\right)$ yang terdiri dari $\mathrm{X} 1 \_1$ hingga X1_4 masing-masing menghasilkan skor r-hitung (total korelasi) lebih besar $(>$ ) dari rtable $(0,1986)$, artinya sah atau valid.

Tabel 2. Hasil uji Reliabilitas untuk instrumenPengetahuan $\left(\mathrm{X}_{1}\right)$

\section{Reliability Statistics}

\begin{tabular}{|c|r|}
\hline $\begin{array}{c}\text { Cronbach's } \\
\text { Alpha }\end{array}$ & N of ltems \\
\hline, 853 & 4 \\
\hline
\end{tabular}

Sumber: Output SPSS (2020)

Instrumen variabel Pengetahuan $\left(\mathrm{X}_{1}\right)$ yang mencakup 4 (empat) item memiliki skor cronbach's alphasebesar 0,853 (lebih dari 0,6), artinya keseluruhan item pernyataanvariabel Pengetahuan $\left(\mathrm{X}_{1}\right)$ memiliki reliabilitas yang layak untukdigunakan sebagai instrumen penelitian.

Tabel 3. Hasil uji item pernyataan untuk variabel Kemampuan Ekonomi $\left(\mathrm{X}_{2}\right)$

Item-Total Statistics

\begin{tabular}{|l|r|r|r|r|}
\hline & $\begin{array}{c}\text { Scale Mean if } \\
\text { Item Deleted }\end{array}$ & $\begin{array}{c}\text { Scale } \\
\text { Variance if } \\
\text { Item Deleted }\end{array}$ & $\begin{array}{c}\text { Corrected } \\
\text { Item-Total } \\
\text { Correlation }\end{array}$ & $\begin{array}{c}\text { Cronbach's } \\
\text { Alpha if Item } \\
\text { Deleted }\end{array}$ \\
\hline X2_1 & 17,2100 & 5,622 &, 581 &, 859 \\
X2_2 & 17,0300 & 6,272 &, 585 &, 851 \\
X2_3 & 16,9700 & 5,343 &, 813 &, 793 \\
X2_4 & 16,9900 & 5,909 &, 619 &, 843 \\
X2_5 & 17,0000 & 5,333 &, 807 &, 794 \\
\hline
\end{tabular}

Sumber: Output SPSS (2020)

Keseluruhan butir pernyataan untuk variabel Kemampuan Ekonomi $\left(\mathrm{X}_{2}\right)$ yang terdiri dari X2_1 hingga X2_5 masing-masing menghasilkan skor r-hitung (total korelasi) lebih besar (>) dari r-table $(0,1986)$, artinya sah atau valid. 


\section{Buana Akuntansi}

Vol. 5 No. 2

ISSN 2528-1119

E-ISSN 2580-5452

Tabel 4. Hasil uji Reliabilitas untuk instrumenKemampuan Ekonomi $\left(\mathrm{X}_{2}\right)$

\section{Reliability Statistics}

\begin{tabular}{|c|r|}
\hline $\begin{array}{c}\text { Cronbach's } \\
\text { Alpha }\end{array}$ & Nof ltems \\
\hline, 859 & 5 \\
\hline
\end{tabular}

Sumber: Output SPSS (2020)

Instrumen variabel Kemampuan Ekonomi $\left(\mathrm{X}_{2}\right)$ yang mencakup 5 (lima) item memiliki skor cronbach's alphasebesar 0,859 (lebih dari 0,6), artinya keseluruhan item pernyataanvariabel Kemampuan Ekonomi $\left(\mathrm{X}_{2}\right)$ memiliki reliabilitas yang layak untukdigunakan sebagai instrumen penelitian.

Tabel 5. Hasil uji item pernyataan untuk variabel Persepsi $\left(X_{3}\right)$

\begin{tabular}{|l|r|r|r|r|}
\hline & $\begin{array}{c}\text { Item-Total Statistics } \\
\text { Scale Mean if } \\
\text { Item Deleted }\end{array}$ & $\begin{array}{c}\text { Scale } \\
\text { Variance if } \\
\text { Item Deleted }\end{array}$ & $\begin{array}{c}\text { Corrected } \\
\text { Item-Total } \\
\text { Correlation }\end{array}$ & $\begin{array}{c}\text { Cronbach's } \\
\text { Alpha if Item } \\
\text { Deleted }\end{array}$ \\
\hline X3_1 & 16,7400 & 4,720 &, 597 &, 780 \\
X3_2 & 16,5000 & 4,313 &, 720 &, 742 \\
X3_3 & 16,4900 & 4,394 &, 661 &, 760 \\
X3_4 & 17,0500 & 4,735 &, 436 &, 836 \\
X3_5 & 16,6600 & 4,772 &, 650 &, 768 \\
\hline
\end{tabular}

Sumber: Output SPSS (2020)

Keseluruhan butir pernyataan untuk variabel Persepsi $\left(\mathrm{X}_{2}\right)$ yang terdiri dari X3_1 hingga X3_5 masing-masing menghasilkan skor r-hitung (total korelasi) lebih besar (>) dari r-table $(0,1986)$, artinya sah atau valid.

Tabel 6. Hasil uji Reliabilitas untuk instrumen Persepsi $\left(X_{3}\right)$

\section{Reliability Statistics}

\begin{tabular}{|c|r|}
\hline $\begin{array}{c}\text { Cronbach's } \\
\text { Alpha }\end{array}$ & N of ttems \\
\hline, 814 & 5 \\
\hline
\end{tabular}

Sumber: Output SPSS (2020)

Instrumen variabel Persepsi $\left(\mathrm{X}_{3}\right)$ yang mencakup 5 (lima) item memiliki skor cronbach's alphasebesar 0,814 (lebih dari 0,6), artinya keseluruhan item pernyataanvariabel Persepsi $\left(\mathrm{X}_{3}\right)$ memiliki reliabilitas yang layak untukdigunakan sebagai instrumen penelitian.

Tabel 7. Hasil uji item pernyataan untuk variabel Minat Kepesertaan BPJS (Y) 


\section{Buana Akuntansi}

Vol. 5 No. 2

ISSN 2528-1119

E-ISSN 2580-5452

Item-Total Statistics

\begin{tabular}{|l|r|r|r|r|}
\hline & $\begin{array}{c}\text { Scale Mean if } \\
\text { Item Deleted }\end{array}$ & $\begin{array}{c}\text { Scale } \\
\text { Variance if } \\
\text { Item Deleted }\end{array}$ & $\begin{array}{c}\text { Corrected } \\
\text { Item-Total } \\
\text { Correlation }\end{array}$ & $\begin{array}{c}\text { Cronbach's } \\
\text { Alpha if Item } \\
\text { Deleted }\end{array}$ \\
\hline Y_1 & 17,2500 & 6,088 &, 540 &, 801 \\
Y_2 & 17,4800 & 5,707 &, 564 &, 794 \\
Y_3 & 17,5400 & 5,241 &, 622 &, 778 \\
Y_4 & 17,6200 & 5,147 &, 663 &, 764 \\
Y_5 & 17,5900 & 5,376 &, 656 &, 767 \\
\hline
\end{tabular}

Sumber: Output SPSS (2020)

Keseluruhan butir pernyataan untuk variabel Minat Kepesertaan BPJS (Y)yang terdiri dari Y_1 hingga Y_5 masing-masing menghasilkan skor r-hitung (total korelasi) lebih besar (>) dari r-table $(0,1986)$, artinya sah atau valid.

Tabel 8. Hasil uji Reliabilitas untuk instrumenMinat Kepesertaan BPJS (Y)

Reliability Statistics

\begin{tabular}{|c|r|}
\hline $\begin{array}{c}\text { Cronbach's } \\
\text { Alpha }\end{array}$ & Nof ltems \\
\hline, 817 & 5 \\
\hline
\end{tabular}

Sumber: Output SPSS (2020)

Instrumen variabel Minat Kepesertaan BPJS (Y) yang mencakup 5 (lima) item memiliki skor cronbach's alphasebesar 0,817 (lebih dari 0,6), artinya keseluruhan item pernyataanvariabel Minat Kepesertaan BPJS (Y) memiliki reliabilitas yang layak untuk digunakan sebagai instrumen penelitian.

\subsection{Uji Hipotesis}

Tabel 9. Hasil Uji Regresi Berganda

\begin{tabular}{|c|c|c|c|c|c|c|c|c|}
\hline \multicolumn{9}{|c|}{ Coefficients ${ }^{a}$} \\
\hline \multirow{2}{*}{\multicolumn{2}{|c|}{ Model }} & \multicolumn{2}{|c|}{$\begin{array}{l}\text { Unstandardiz ed } \\
\text { Coefficients }\end{array}$} & \multirow{2}{*}{$\begin{array}{c}\begin{array}{c}\text { Standardized } \\
\text { Coefficients }\end{array} \\
\text { Beta }\end{array}$} & \multirow[b]{2}{*}{$t$} & \multirow[b]{2}{*}{ Sig. } & \multicolumn{2}{|c|}{ Collinearity Statistics } \\
\hline & & $\mathrm{B}$ & Std. Error & & & & Tolerance & VIF \\
\hline$\overline{1}$ & (Cons tant) & 8,277 & 2,086 & & 3,968 & 000 & & \\
\hline & Pengetahuan & ,221 & 150 & ,188 & 1,468 & 145 & ,434 & 2,307 \\
\hline & Kemampuan Ekonomi & ,338 & 105 & 345 & 3,229 & ,002 & ,622 & 1,608 \\
\hline & Persepsi & 134 & .155 & 122 & .862 & .391 & .354 & 2,824 \\
\hline
\end{tabular}

a. Dependent Variable: Minat Kepesertaan BPJS

Sumber: Output SPSS (2020)

Variabel Pengetahuan $\left(X_{1}\right)$ menghasilkan koefisien regresi sebesar 0,221 dengan probabilitas signifikansi sebesar 0,145 (lebih besar dari 0,05), hal ini berarti terdapat pengaruh atas variabel Pengetahuan terhadap Minat Kepesertaan BPJS (Y) secara tidak signifikan.Variabel Kemampuan Ekonomi $\left(\mathrm{X}_{2}\right)$ menghasilkan koefisien regresi sebesar 0,338 dengan probabilitas signifikansi sebesar 0,002 (lebih kecil dari 0,05), hal ini berarti terdapat 
pengaruh atas variabel Kemampuan Ekonomi terhadap Minat Kepesertaan BPJS (Y) secara signifikan.Variabel Persepsi $\left(X_{3}\right)$ menghasilkan koefisien regresi sebesar 0,134 dengan probabilitas signifikansi sebesar 0,391 (lebih besar dari 0,05), hal ini berarti terdapat pengaruh atas variabel Persepsi terhadap Minat Kepesertaan BPJS (Y) secara tidak signifikan.

\subsection{Pembahasan}

\subsubsection{Hubungan antara Variabel Pengetahuan terhadap minat kepersertaan sektor informal dalam BPJS} Kesehatan Di Kota Surakarta

Dari hasil olah data (Tabel 9) dapat dijelaskan variabel Pengetahuan berpengaruh positif namun tidak signifikan terhadap minat kepersertaan BPJS Kesehatan, dengan hasil koefisien regresi sebesar 0,221 dan sig. 0,145 > 0,05 itu artinya semakin tinggi tingkat pengetahuan masyarakat khususnya dalam hal ini sektor informal (wiraswasta/pedagang) maka akan semakin menaikkan minat kepersertaan BPJS Kesehatan.

Hasil penelitian Tidak berpengaruh kuat dapat dikarenakan rendahnya pendidikan masyarakat yang dapat berpengaruh terhadap daya tangkap terhadap informasi BPJS kesehatan yang diperoleh tidak dapat di pahami, sehingga walaupun masyarakat pernah melihat atau mendengar informasi mengenai BPJS Kesehatan mereka akan mengabaikannya karena merasa informasi tersebut tidak terlalu penting. Oleh karena itu penting dilakukan penyuluhan secara langsung dan berkala tidak hanya dilakukan sekali saja kepada masyarakat mengenai BPJS Kesehatan sehingga masyarakat pedesaan mengerti betul maskud tujuan dan manfaat dari penyelengaraan BPJS Kesehatan, banyak sektor informal (wiraswastapedagang) yang tidak mengakses BPJS disebabkan karena tidak adanya informasi yang diterima olehmasyarakat mengenai BPJS Kesehatan. Informasi yang diterima saat ini kurang mendapatkan tanggapan karna minim akses untuk mendapatkan berbagai macam informasi itu sendiri, selama ini informasi yang diterima oleh masyarakat adalah dari berita-berita melalui tv, dan media sosial lainnya. Sehingga sektor informal (wiraswasta/pedagang)kurang begitu mengetahui informasi terbaru seperti tarif pelayanan rumah sakit rekanan, faskes dan lain sebagainya terkait dengan program BPJS Kesehatan. Hasil wawancara terhadap responden yang tidak mengakses BPJS mengatakan di Kota Surakarta minim diadakan penyuluhan mengenai BPJS Kesehatan itu sendiri.

Penelitian ini tidak sependapat dengan penelitian Atipah, Salma (2016) yang menyatakan bahwa faktor pengetahuan berdampak signifikan atas partisipasi program JKN dan Jamkesda serta aksesibilitas minat program BPJS (Salma, 2016; Atipah, 2016; Wijayanto), sedangkan sejalan dengan penelitian Pangestika (2017) yang tidak membuktikan hubungan faktor pengetahuan dengan minat kepesertaan BPJS.

\subsubsection{Hubungan antara Variabel Kemampuan Ekonomi terhadap minat kepersertaan sektor informal dalam BPJS Kesehatan Di Kota Surakarta}

Dari hasil olah data (Tabel 9) dapat dijelaskan variabel Kemampuan Ekonomi berpengaruh positif dan signifikan terhadap minat kepersertaan BPJS Kesehatan, dengan hasil koefisien regresi sebesar 0,338 dan sig. 0,002 < 0,005 itu artinya semakin tinggi tingkat kemampuan ekonomi masyarakat khususnya dalam hal ini sektor informal (wiraswasta/pedagang) maka akan semakin menaikkan minat kepersertaan BPJS Kesehatan. 
Tingkat ekonomi seseorang akan mempengaruhi kemampuan untuk mengakses pelayanan kesehatan yang ada. Memiliki penghasilan yang cukup dapat mendorong dan menjadi bahan pertimbangan seseorang untuk menjadi peserta BPJS Kesehatan. Hasil ini berpengaruh kuat dalam kepesertaan BPJS Sektor informal di Surakarta, menandakan bahwa peserta sektor informal (wiraswasta/ pedagang)dengan pengasilannya tidak menentu dan ada beberapa masih dibawah standar UMKtidak berkeberatan mengikuti program asuransi kesehatan BPJS yang masih dianggap banyak orang memberatkan karena harus membayar iuran setiap bulannya.

Penelitian ini sependapat dengan penelitian Salma, Melinda, dkk. (2016) serta Wijayanto (2017) yang menyatakan bahwa dukungan pendapatan dan situasi ekonomi berdampak signifikan atas partisipasi program JKN dan keikusertaan BPJS. Penelitian ini tidak sependapat dengan penelitian Pangestika (2017) yang tidak membuktikan hubungan faktor pendapatan dengan minat kepesertaan BPJS.

\subsubsection{Hubungan antara Variabel Persepsi terhadap minat kepersertaan sektor informal dalam BPJS Kesehatan Di Kota Surakarta}

Dari hasil olah data (Tabel 9) dapat dijelaskan variabel Persepsi berpengaruh positif namun tidak signifikan terhadap minat kepersertaan BPJS Kesehatan, dengan hasil koefisien regresi sebesar 0,134 dan sig. 0,391 >0,005 itu artinya semakin tinggi persepsi masyarakat khususnya dalam hal ini sektor informal (wiraswasta/pedagang) maka akan semakin menaikkan minat kepersertaan BPJS Kesehatan.

Persepsi nilai merupakan penilaian konsumen secara keseluruhan terhadap kegunaan suatu produk atau jasa berdasarkan persepsi atas apa yang telah didapat. Nilai merupakan ikatan yang kuat pada persepsi konsumen atas manfaat yang dipersepsikan pelanggan (perceived value). Nilai yang dirasakan (perceived value) juga digunakan oleh konsumen untuk mempertimbangkan berbagai aspek layanan dengan biaya yang ditawarkan oleh beberapa perusahaan.Kemudahan dalam mendapatkan pelayanan akan terlihat dari mudahnya pasien mendapatkan informasi pelayanan dan prosedur pelayanan. fasilitas lain baik itu sarana dan prasarana serta infrastruktur misalnya, ruang tunggu yang nyaman, dan fasilitas lainnya akan membantu dan dapat memberikan pelayanan yang maksimal pada masyarakat sebagai pengguna pelayanan. Pelayanan yang baik adalah pelayanan yang memberikan rasa nyaman dan kepuasan bagi pasien beserta keluarganya.Hal ini sejalan dengan penelitian Melinda (2016) yang menunjukan ada hubungan antara Kemampuan Ekonomi dengan minat kepersertaan sektor informal dalam BPJS Kesehatan di Kota Surakarta.Semakin tinggi persepsi baik masyarakat terhadap BPJS Kesehatan maka semakin besar minat kepesertaan dalam BPJS Kesehatan.

Penelitian ini tidak sependapat dengan penelitian Melinda, dkk. (2016) yang menyatakan bahwa faktor sikap, persepsi ekonomi atas minat membuktikan secara signifikan hubungannya dengan minat keikutsertaan BPJS (Melinda dkk., 2016), dan juga sikap dan perilaku juga atas partisipasi program JKN dan Jamkesda (Salma, 2016; Atipah, 2016).

\section{Kesimpulan, Keterbatasan, dan Saran}

Variabel yang berhubungan dan membuktikan prediksi minat masyarakat sektor informal dalam keikutsertaan BPJS Kesehatan di kota Surakarta adalah kemampuan ekonomi, sementara variabel pengetahuan dan persepsi tidak mampu memprediksi minat kepesertaan masyarakat 
dalam BPJS Kesehatan. Hasil penelitian ini dapat menambah wawasan peneliti mengenai hubungan pengetahuan, kemampuan ekonomi dan persepsi dengan aksesibilitas BPJS, sehingga peneliti dapat memberikan kontribusi penelitian kepada tenaga kesehatan dan wawasan kepada masyarakat, khususnya pada sektor informal (wiraswasta/pedagang) di Surakarta mengingat betapa pentingnya kepesertaan BPJS kesehatan yang bertujuan untuk meningkatkan taraf kesehatan masyarakat.

Saran penelitian bagi Institusi kesehatan setempat agar melakukan sosialisasi kepada masyarakat tentang BPJS supaya masyarakat mengerti dan memahami secara mendalam tentang program dan fitur penting dari BPJS Kesehatan serta aksesibilitasnya. Penelitian selanjutnya dapat dapat melakukan studi lanjutan tentang faktor-faktor yang mempengaruhi aksesibilitas BPJS pada masyarakat dan faktor lain yang mempengaruhi pengetahuan kepala keluarga tentang BPJS seperti dukungan petugas kesehatan.

\section{Daftar Pustaka}

Achmadi, U. F. (2013). Kesehatan Masyarakat Teori Dan Aplikasi. Jakarta: Rajawali Pers.

Atipah, (2016), Faktor yang Berpengaruh Terhadap Minat Masyarakat Dalam Keikutsertaan Program Jamkesda Di Desa Banjarlor Kecamatan Banjarharjo kabupaten Brebes, Universitas Negeri Semarang.

Badan Pusat Statistik. Kota Surakarta Dalam Angka 2019

(Https://id.scribd.com/document/3945), ada hubungan sosialisasi dengan minat masyarakat dalam kepesertaan BPJS44433/Kecamatan-Mantikulore-DalamAngka-2018-doc). Diakses 27 Desember 2018.

BPJS Kesehatan Kota Surakarta. https://jateng.idntimes.com/news/jateng/larasatirey/pemkot-solo-hanya-sanggup-bayar-kenaikan-iuran-bpjs-sampai-mei. Diakses bulan Februari 2020

Davis, W.S., Yen, D.C. (1998). The Information System Consultant's Handbook: Systems Analysis and Design: CRC press.

Khristiana, Y., Octaviani, A., \& Sapariyah, R. A. (2018). Pemberdayaan Potensi Masyarakat Desa Matesih Kabupaten Karanganyar (Pemanfaatan Kain Flanel). WASANA NYATA (Jurnal Pengabdian Pada Masyarakat), 2(1), 13-18.

Melinda, Suparwati. A, Suryoputro. A. (2016), Faktor-faktor yang berhubungan dengan minat masyarakat dalam keikutsertaan BPJS mandiri di Kecamatan Bener Kabupaten Purworejo. Fakultas Kesehatan Masyarakat Universitas Diponegoro.

Notoatmodjo. S, (2007), Kesehatan Masyarakat Ilmu dan Seni, PT Rineka Cipta, Jakarta.

Notoatmodjo, S. (2010). Ilmu Perilaku Kesehatan. Jakarta: Rineka Cipta

Pangestika. V.B, Jati. S.P, Sriatmi. A. (2017). Faktor-faktor yang berhubungan dengan kepesertaan sektor informal dalam BPJS Kesehatan Mandiri di Kelurahan Poncol, Kecamatan Pekalongan Timur, Kota Pekalongan.Bagian Administrasi dan Kebijakan Kesehatan, Fakultas Kesehatan Masyarakat Universitas Diponegoro.

Rismayadi, B., \& Maemunah, M. (2018). Creative Economy to Increase Community Revenue Based on Tourism Object, Medalsari Village, Pangkalan District Karawang Regency. Journal of Accounting, Business and Finance Research, 3(1), 28-35. 


\section{Buana Akuntansi}

Rohmawati, Desy, (2014), Hubungan Pengetahuan, Sikap Dan Sosial Ekonomi Dengan Pemilihan Jenis Iuran Keikutsertaan JKN Mandiri Pada Wilayah Cakupan JKN Tertinggi di Surakarta, Fakultas Ilmu Kesehatan Masyarakat Universitas Muhammadiyah, Surakarta.

Salma, (2016), Faktor-Faktor Yang Berhubungan Dengan Keikutsertaan Masyarakat Dalam Jaminan Kesehatan Nasional Di Desa Tegalsari Kabupaten Ponorogo 2015, Universitas Muhammadiyah Surakarta.

Sani, A., Wiliani, N., \& Husain, T. (2019). Spreadsheet Usability Testing in Nielsen's Model among Users of ITSMEs to Improve Company Performance. European Journal of Scientific Exploration, 2(6), 1-9.

Sugiyono. (2016). Metode Penelitian Kombinasi (Mixed Methods). (M. Sutopo, Ed.) Bandung: CV. Alfabeta.

Sumardi, M, (2007), Kemiskinan Dan Kebutuhan Pokok, Rajawali, Jakarta.

Supranto, J., \& Limakrisna, N. (2019). Petunjuk Praktis Penelitian Ilmiah untuk Menyusun Skripsi, Tesis dan Disertasi (5 ed.). Bogor: Penerbit Mitra Wahana Media.

Wijayanto, W.P. (2017), Hubungan Pengetahuan dan Kemampuan Ekonomi Masyarakat Terhadap Aksesibiltas BPJS. Program Studi Ilmu Keperawatan STIKes Aisyah Pringsewu Lampung. 